\title{
Immunohistochemical evaluation of the influence of L-arginine on biomarkers of environmental (cellular) stress in the kidneys of pregnant female rats
}

\author{
Agnieszka Pedrycz ${ }^{1}$, Piotr Siermontowski \\ ${ }^{1}$ Department of Histology and Embryology medical University in Lublin, Poland \\ 2 Department of Maritime and Hyperbaric Medicine Military Institute of Medicine, Gdynia, Poland
}

Pedrycz A, Siermontowski P E. Immunohistochemical evaluation of the influence of L-arginine on biomarkers of environmental (cellular) stress in the kidneys of pregnant female rats. Ann Agric Environ Med. 2017; 24(1): 121-128. doi: 10.5604/12321966.1230677

\begin{abstract}
Introduction. Kidney damage during pregnancy constitutes a diagnostic and therapeutic challenge. However, it is not entirely known whether a kidney condition recognised before the pregnancy releases an organism's response to pregnancy, or whether pregnancy itself worsens kidney function.

Objective. The aim of the study was immunohistochemical evaluation of cells of kidneys of pregnant rats under the influence of nitric oxide (NO), with measurement of the immunoexpression of cellular stress markers ( $p-53$, HSP 70). The dose of administered L-arginine (NO substrate) was approximated to that applied in obstetrics in gestosis prevention and treatment in pregnant women.

Materials and method. 60 female rats used in experiment were divided into 6 groups: 3 experimental and 3 control. The females from experimental groups were administered L-arginine $(40 \mathrm{~g} / \mathrm{kg}$, per os) every other day starting from the seventh day or pregnancy. The animals were decapitated on the $10^{\text {th }}, 20$ th day of pregnancy, and 10 days after the delivery. Kidneys taken from decapitated rats were evaluated using the immunohistochemical three step method. HSP 70 and p-53 proteins were detected.

Conclusions. L-arginine increased the expression of p-53 protein - on the 10th day of pregnancy, which increased at the end of pregnancy; however, 10 days after delivery the level dropped below that observable during physiological pregnancy. Hormonal changes in physiological pregnancy cause an increase in expression of the p-53 (cell stress marker) in the epithelial cells of renal tubules, mainly at the end of pregnancy (20th day). 10 days after the delivery, this expression decreases. The expression of HSP-70 protein increases already on the 10th day of pregnancy and maintains a similar level throughout the pregnancy, but is reduced after the puerperium.
\end{abstract}

\section{Key words}

nitric oxide, cellular stress, kidneys, pregnancy, immunohistochemistry

\section{INTRODUCTION}

In 1999, Professor Żylicz discovered protective proteins that prevent the impact of harmful factors and regulate the functioning of numerous basic cellular processes. Ron Lasky referred to them as 'chaperone proteins' as they inhibit the process of formulation or split the already structured multicellular, often insoluble, protein aggregations [1].

The inhibited activity of protective proteins may be an underlying reason for multiple diseases. Protective proteins serve highly significant functions, including: assistance during DNA replication and transcription, participation in the correct folding of new proteins and their importation to the organelles, receptor activation and protein degradation, enabling the functioning of the so-called MHC complexes responsible for correct reaction of the immunological system, creating a new universal cell protection system against external conditions, and used in the production of anticancer vaccines.

Address for correspondence: Agnieszka Pedrycz, Department of Histology and Embryology / Laboratory of Experimental Cytology, Medical University, 20-080 Lublin, Poland

E-mail: apw4@wp.pl

Received: 30 August 2013; accepted: 29 April 2014; first published on January 2017
The signal to commence a pathological process in a cell is an increased expression of heat shock proteins, i.e. HSP-70, known as a protein which protects endangered cells against damaging enzymatic and structural proteins that could result in cellular dysfunction.

Protein p-53 - is the so-called 'guardian of the genome', in which the expression increase is a result of an early damage to a cell's genetic material. This is a proof of DNA degradation in a cell nucleus [2].

Becoming acquainted with the expression of the proteins HSP 70 and p 53 may contribute to undertaking early pharmacological action. The HSP 70, known as a heat shock protein, also referred to as a protective protein (chaperone), in addition to its protective function against cell destruction is characterized by some other features:

- it shows an observable increase in its concentration in cytoplasm after a cell's exposure to various damaging conditions [3], i.e. stress, UV radiation, antibiotics, ethanol, viruses, bacteria, and $\mathrm{pH}$ fluctuations [4];

- helps in importing proteins through cell organelle membranes and prevents the formation of incorrect, nonfunctional protein structure [5];

- eliminates erroneous structures and induces degradation of denature proteins whose reconstruction is not possible 
(stress proteins) [6]. Prevents aggregation and incorrect folding of proteins [7];

- inhibits cell death induced by cytochrome C;

- inhibits AIF - a mitochondrial factor activating apoptosis;

- protects other proteins from the destruction of their spatial conformation prevents kinase activated by stress, i.e. JNK;

- inhibits caspase 3-like protease by associating pro-caspase 3 and 7 (prevents over-expression of caspase 3 - apoptosis producer).

The HSP 70 included in the group of protective proteins, acts as a monomer, detecting uncovered hydrophobic protein segments. It also takes part in shaping newly-produced proteins. The energy coming from ATP helps those proteins to combine and disconnect from hydrophobic parts of an irregular protein particle. Thus, it may be stated that HSP 70 serves multiple functions by restoring the proper structure of proteins denatured by excess temperature, selecting irregular proteins and directing them onto the route to destruction, and participating in protein importation through biological membranes.

The expression of coding genes of the heat shock protein HSP 70 is induced by the so-called environmental stress, i.e. the effect of a high temperature and the impact of heavy metals, alcohols, amino acids, free radicals, UV radiation and other conditions.

P-53 protein is a phosphoprotein activated by damaged DNA. It inhibits cellular cycle in the G1 phase, thus allowing for cell repair. This genome guardian serves many functions. It stimulates the production of $\mathrm{p}-21$ protein, which inhibits kinases necessary in cellular cycle [8]. When cell repair is not feasible it commences the process of apoptosis [9]. P-53 has an anti-apoptotic effect by blocking BCL-2 gen [9]. It also has an pro-apoptotic effect by increasing the amount of BAX proteins and activating the production of AIP 1 protein in cells subjected to apoptosis which, by combining with mitochondria, releases from them cells stimulating caspases [10]. AIP 1 protein is produced after a dozen or so hours following DNA damage, thus having an impact on the repair of the damaged genetic material.

Recognising the expression of HSP 70 and p 53 proteins signalling the commencement of a pathological process in a cell may contribute to an early pharmacological reaction

Kidneys are organs characterized as showing the earliest reaction in the form of changes in cell metabolism and morphology during pregnancy. Changes taking place in kidneys constitute one of the reasons for gestosis (pregnancyinduced poisoning) with the main elements including hypertension (risk of preeclampsia), oedemas and proteinuria.

In the available literature, the authors were unable to find an answer to the question: how does exogenous nitric oxide (produced in an organism from exogenous L-arginine or NO carriers) influence the kidneys of pregnant women? This, despite the fact that exogenous nitric oxide is used in the treatment of pregnancy pathology, one of the reasons for which are the changes present in the kidneys.

Nitric oxide is a regulator of numerous processes taking part in human and animal organisms. As a result of many scientific studies carried out over the 340 years since its discovery as a chemical compound in 1770 by Joseph Priestley, it is known that NO is produced in an organism by various cells, including endothelium cells, but also by macrophages, hepatocytes, nerve endings and some neurons, neutrophils, mastocytes, monocytes and blood platelets. Nitric oxide is a colourless gas subjected to a series of metabolic changes (1998 - Nobel Prize in medicine - Robert Furghott, Louis Ignarro and Ferid Murad); it oxides easily to nitrate $\mathrm{NO} 2$ without the help of enzymes, whereas the final NO metabolite is extracted in urine. In an organism it is produced from L-arginine in the presence of nitric oxide synthase (NOS) [11] in a twostage oxidization reaction: L-arginine+NADPH+O2--- $>\mathrm{L}-$ citrulline $+\mathrm{NADP}+\mathrm{H} 2)+\mathrm{NO}$. By reacting with L-aspartic acid in the cells of endothelium, L-citrulline leads to L-arginine resynthesis. Several mechanisms of the effects of nitric oxide are known:

1) Activation of the cytosolic guanylate cyclase enzyme which catalyses the reaction: GTP----> cGMP+PPi; the cGMP produced as a result of this reaction activates the dependent phosphodiesterases and kinases, as well as ion channels;

2) S-nitrolisation of proteins - a reaction regulating numerous vital processes of cells, including phosphorylation; the created S-nitrosothiols (proteins) play a crucial role in the transduction of DNA repair signal, blood pressure control, regulation of ion channels and neurotransmission;

3) Activation of PARP (poly-(ADP-ribose)-polymerase), the activity of which consumes large quantities of NAD,

NO excess or deficiency has a significant impact on the pathogenesis of numerous diseases, including degenerative diseases of the nervous system, autoimmune diseases, inflammations, hypercholesterolaemia, atheromatosis and hypertension. L-arginine (nitric oxide substrate) is used in gynaecology to broaden vessels and lower hypertension in gestosis.

However, since nitric oxide has not been completely examined, depending on its dosage it may either protect a cell from death or induce it. Heat shock proteins, being determinants of the commencement of a pathological process in a cell, could contribute to a pharmacological reaction.

The above-mentioned proteins have been evaluated in conditions of an altered hormonal environment and under the influence of L-arginine. The results of this experiment constitute a significant step in the research on cell death, and provide support in the research on NO effect on the organs of pregnant female rats which were subjected to the activity of L-arginine, the substrate of nitric oxide (NO). The doses of the administered medicine were close to those used in obstetrics to prevent and treat gestosis in pregnant women.

It is known that kidney damage during pregnancy constitutes a diagnostic and therapeutic challenge to nephrologists and obstetricians. The organs selected for the research - the kidneys - are the first to react with changes in cell metabolism and morphology during pregnancy, which is why their lesions are one of the reasons for gestosis.

The above-mentioned tubule cells were examined with the following purposes:

a) to check for HSP70 protein expression - marker of cell's environmental stress;

b) to check for $\mathrm{p} 53$ protein expression - marker of cell nucleus damage ('genome guardian').

Defining the expression of these proteins may contribute to early pharmacological reaction because at present it is not known what kind of changes NO itself may produce in the kidneys of pregnant women, despite its application in the treatment of pregnancy pathology. 


\section{MATERIALS AND METHOD}

The experiment was conducted on rats by applying the immunohistochemical method of protein detection and localisation in cells with the use of antibodies. Kidney specimens from pregnant female rats during and after therapy with L-arginine were histologically evaluated in the course of pregnancy ( $10^{\text {th }}$ day), at the end of pregnancy $\left(20^{\text {th }}\right.$ day) and in the period of peurperium ( $10^{\text {th }}$ day after giving birth). The immunohistochemical reaction was also quantitatively evaluated with the use of a computer programme, and the examined material compared with the control and analysed statistically.

The research was carried out on randomly-selected female Wistar rats with initial body weight of 200-250g, aged from $2.5-3$ months. The females were selected in accordance with the simultaneity principle of experimental and control groups. They were kept in the Animal Facility of the Department of Histology and Embryology of the University of Life Sciences in Lublin, Poland, in an ambient temperature of $20+/-2$ degrees Celsius and air humidity of ca. $60 \%$. Both the ambient temperature as well as the lighting and noise alternated slightly during the day. Female rats were placed in standard metal cages with the area of $0.5 \mathrm{~m}^{2}$, each one holding 10 rats. The litter was sawdust replaced at proper frequency.

The research on laboratory animals was approved by the $1^{\text {st }}$ Local Ethical Committee of the Medical University in Lublin, and the $2^{\text {nd }}$ Local Ethical Committee in Lublin at the University of Life Sciences, also in Lublin.

The animals were divided into 6 even groups with 10 females in each. The females from the experimental groups were administered L-arginine in the dose of $40 \mathrm{~g} / \mathrm{kg}$, per os. every other day, starting from the $7^{\text {th }}$ day or pregnancy $(7 x)$. The females from control groups were administered $2 \mathrm{ml}$ of distilled water, per os, every other day, also starting from the $7^{\text {th }}$ day of pregnancy $(7 \mathrm{x})$.

The females were decapitated in the following order:

- experimental group - females inseminated, administered L-arginine and decapitated on the $10^{\text {th }}$ day of pregnancy;

- control group - females inseminated, administered distilled water and decapitated on the $10^{\text {th }}$ day of pregnancy;

- experimental group - females inseminated, administered L-arginine and decapitated on the $20^{\text {th }}$ day of pregnancy;

- control group - females inseminated, administered distilled water and decapitated on the $20^{\text {th }}$ day of pregnancy;

- experimental group - females inseminated, administered L-arginine and decapitated 10 days after giving birth

- control group - females inseminated, administered distilled water and decapitated 10 days after giving birth

At the beginning of the experiment, the females were mated with males. Vaginal swabs were taken each day and examined on microscope slides with the use of an optic microscope. The presence of a vaginal plug or sperm was treated as effective copulation - insemination.

A further experiment was carried out only with those females that were inseminated in the period between the $2^{\text {nd }}$ and the $4^{\text {th }}$ day from mating with males. After decapitation, the kidneys of all animals were examined macroscopically and described. The specimens of rats' kidneys for immunohistochemical evaluation were fixed in $10 \%$ formalin, then dehydrated in a graded alcohol, subjected to xylene and embedded in paraffin. The paraffin blocks were cut with the use of the $5 \mu \mathrm{m}$ microtome and placed on salinized slides. The examination was conducted on 2 preparations from each examined organ of each specimen. After deparaffinization in xylene and decreasing the ethyl concentration, the preparations were subjected to heat treatment: in acidic environment for antibodies against the HSP70 (10mM citrate buffer $\mathrm{pH} 6.0$ ) - $7.5 \mathrm{~min}$ in a microwave oven at $750 \mathrm{~W}$, and after a 5 -min break, $7.5 \mathrm{~min}$ at $375 \mathrm{~W}$; in alkaline environment for antibodies against the p-53(EDTA) $-7.5 \mathrm{~min}$ in a microwave oven at $750 \mathrm{~W}$, and after a 5 -min break $7.5 \mathrm{~min}$ at $375 \mathrm{~W}$.

After cooling for $20 \mathrm{~min}$, the preparations were rinsed with distilled water and placed in TBS buffer (Tris Buffered Saline). Next, the preparations were blocked with endogenous peroxidase by a 20 -min incubation in $0.3 \%$ solution of $\mathrm{H} 2 \mathrm{O} 2$ (99ml of TBS buffer, $0.1 \mathrm{~g} \mathrm{NaN} 3,1 \mathrm{ml} 30 \% \mathrm{H} 2 \mathrm{O} 2$ ). The preparations were rinsed for approx. $10 \mathrm{~min}$ in TBS buffer, then incubated for 60 mins at room temperature with monoclonal mouse primary antibody p-53 (Lab Vision P53 Ab-1; MS-104-PO) in 1/50 solution in TBS/BSA 1\% buffer (bovine serum albumin), and with rabbit primary antibody HSP70 (Lab Vision Ab-3; RB-080-AO) in 1/100 solution in TBS/BSA $1 \%$ buffer.

In order to obtain an immunohistochemical reaction, a kit of ready-to-use reagents (DakoCytomation Company) was applied, which included: biotinylated secondary antibodies against mouse and rabbit antibodies (Biotinylated Link Universal) (15 min of incubation); streptavidin conjugated with horseradish peroxidase (StreptavidinHRP), (15 min of incubation), AEC-substrate - reaction dye with horseradish peroxidase (AEC Substrate chromogen), (15 min of incubation). After the application of each reagent, the preparations were rinsed in TBS buffer for a minimum of $10 \mathrm{~min}$. Next, after staining the preparations with chromogen, they were placed for ca. 1 min into a haematoxylin solution and heavily rinsed with distilled water. The preparations were covered with a slip cover with the use of Aquaetex liquid.

Photographic documentation was prepared with the use of a Colour Video Camera CCD-IRIS (Sony) interfaced with a computer. Negative control was performed in relation to each studied preparation to which no primary antibody had been added.

Immunohistochemical examination results were evaluated qualitatively with regard to the intensity of coloured reaction in the place of an antigen-antibody reaction in the examined rat organs from particular groups, and quantitatively with the use of the Analysis computer programme, version 3 (Soft Imaging System GmbH, Germany). Analysis of the microscopic image in x125 extension evaluating protein expression was carried out by examining 3 randomly-selected spots of each preparation, each with an area of 78,1193.35 $\mathrm{um}^{2}$. The cell area indicating positive reaction (+) was calculated. First, the area of the surface taken into account on mask placement was determined. Next, the range of colours corresponding to antigen-antibody reaction colour on which the mask was to be placed was selected. The mask was then placed (transition to black-white-brinarize image) and the computer detected fields on which the mask was placed (those that became white as a result of mask placement). The area of fields covered by the mask was calculated (partical results) and statistical results were prepared. 
The obtained results were listed in the form of mean values and their standard deviations and subject to statistical analysis with the use of the ONE WAY ANOVA test, admitting a 5\% risk of inference error and difference significance lower or equal to 0.05 . Statistical analysis was conducted in relation to the following: differences in rats' body mass and differences in the average field area of positive immunohistochemical reaction in particular groups with regard to all examined antibodies.

\section{RESULTS}

Female rats from all the experimental and control groups behaved in a similar way in the course of the experiment. They were characterized by similar appetite, thirst and physical activity.

Vaginal plug or sperm was detected in the vaginal swab of 59 females, which was regarded as effective copulation insemination.

58 females were admitted for further experiments - the insemination occurred between the 2 nd and the 4 th day following the mating with male specimens.

Heat Shock Protein - HSP 70

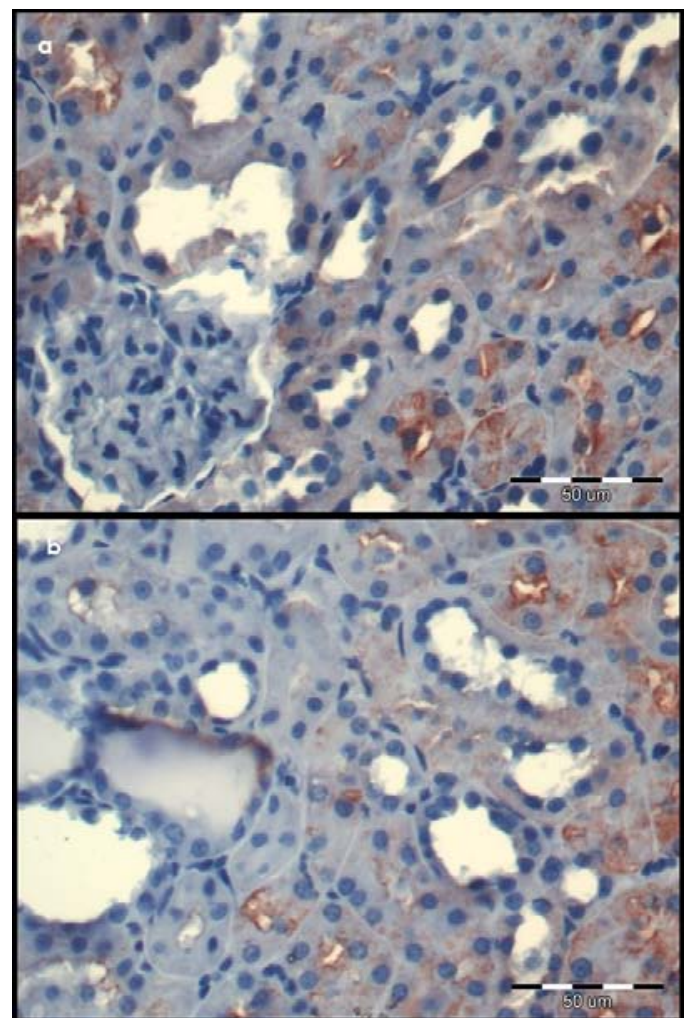

Figure 1. Kidney section of rat decapitated on the $10^{\text {th }}$ day of pregnancy. Intensive IHSP70 mmunohistochemical reaction. $\mathrm{AEC}+\mathrm{H}$ staining.

a - Experimental group I - pregnant rats treated with L-ARG

$\mathrm{b}$ - Control group II - pregnant rats treated with $\mathrm{NaCl}$

The reaction for HSP70 protein on the $20^{\text {th }}$ day of physiological pregnancy (average area of positive immunohistochemical reaction: $40018.08+/-1885.80 \mu \mathrm{m}^{2}$ ) remained at the same level as on the $10^{\text {th }}$ day of pregnancy (average area of positive immunohistochemical reaction: $40534.36+/-2654.65 \mu \mathrm{m}^{2}$ ) (Student's t-test $\left.\mathrm{p}=0.14\right)$. It became

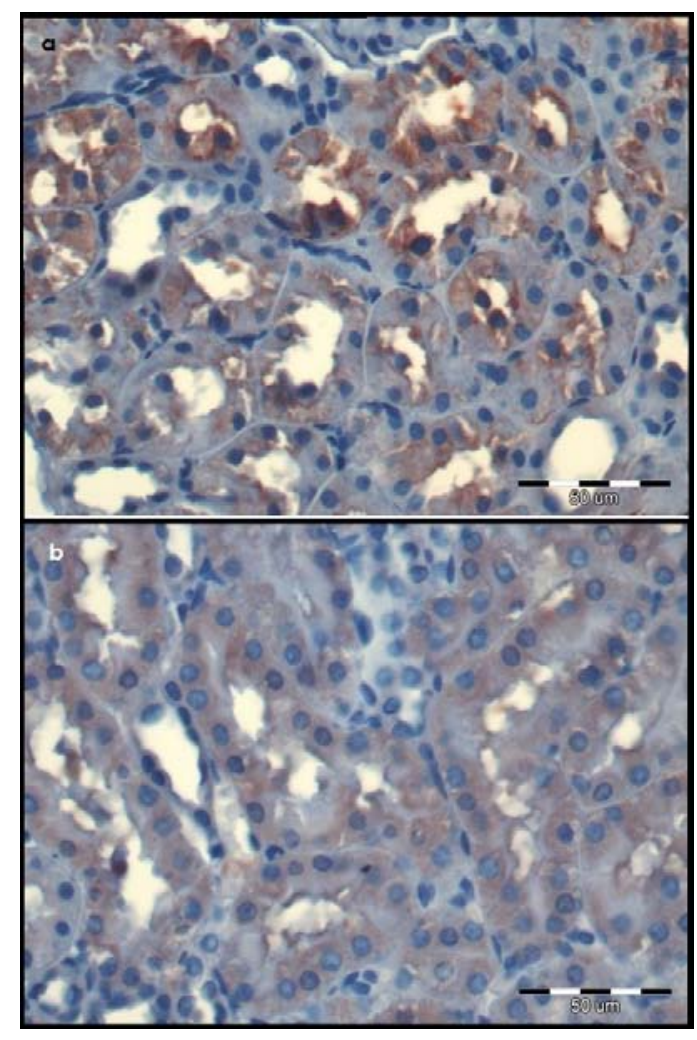

Figure 2. Kidney section of rat decapitated on the $20^{\text {th }}$ day of pregnancy. Intensive HSP70 mmunohistochemical reaction. AEC $+\mathrm{H}$ staining.

a - Experimental group III - pregnant rats treated with L-ARG $\mathrm{b}-\mathrm{Control}$ group IV - pregnant rats treated with $\mathrm{NaCl}$

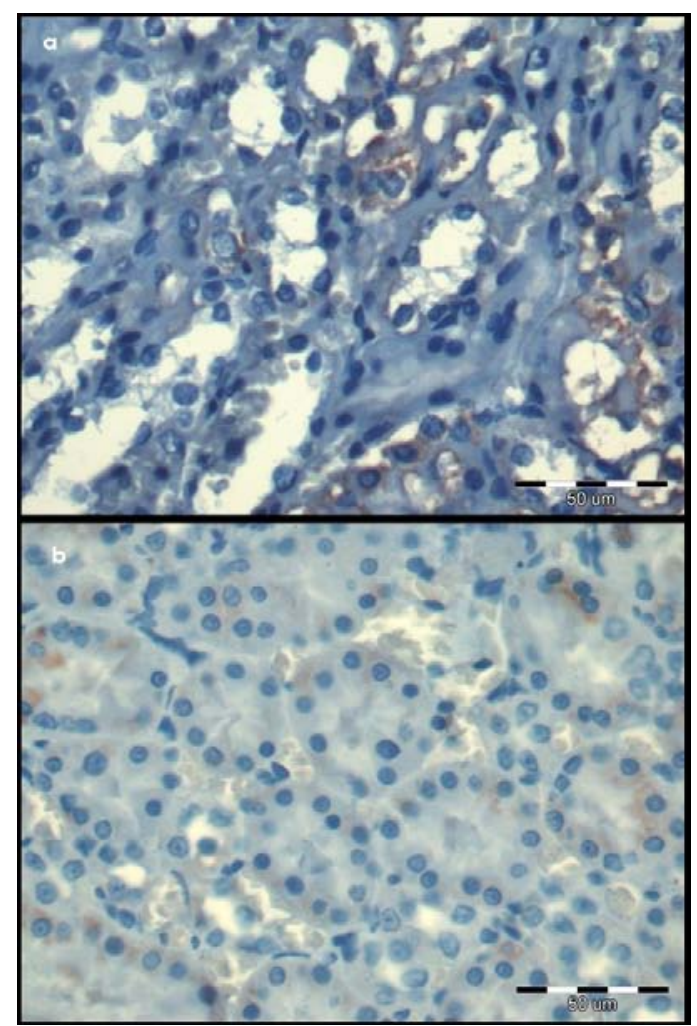

Figure 3. Kidney section of rat decapitated the $10^{\text {th }}$ day after delivery. Weak HSP70 immunohistochemical reaction. AEC $+\mathrm{H}$ staining.

a - Experimental group V - pregnant rats treated with L-ARG $\mathrm{b}$ - Control group $\mathrm{VI}$ - pregnant rats treated with $\mathrm{NaCl}$ 
significantly statistically lower 10 days after giving birth. The average area of positive immunohistochemical reaction: $\left.12282.46+/-1427.17 \mu \mathrm{m}^{2}\right)($ Student's t-test $\mathrm{p}<0.001)$.

The reaction for HSP70 protein on the $20^{\text {th }}$ day of experimental pregnancy (average area of positive immunohistochemical reaction: $50617.06+/-2312.34 \mu \mathrm{m}^{2}$ ) was similar to that described on the $10^{\text {th }}$ day of pregnancy (average area of positive immunohistochemical reaction: $51000.71+/-2209.73 \mu \mathrm{m}^{2}$ )(Student's t-test $\mathrm{p}=0.26$ ). It became significantly statistically lower 10 days after giving birth (average area of positive immunohistochemical reaction: $\left.39950.93+/-2086.25 \mu \mathrm{m}^{2}\right)$ in relation to experimental groups 1 and 2) (Student's t-test $\mathrm{p}<0.001$ ).

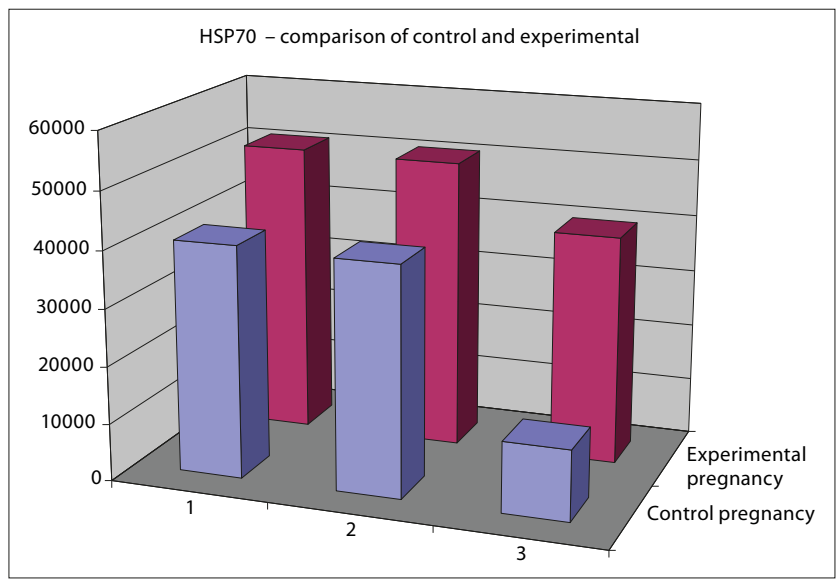

Figure 4. Comparison of the average area of positive immunohistochemical reaction expressed in $\mu \mathrm{m}^{2}$ for HSP70 in control and experimental groups $\left(1-10^{\text {th }}\right.$ day of pregnancy; $2-20^{\text {th }}$ day of pregnancy; $3-10^{\text {th }}$ day after delivery)

In the experimental groups of pregnant rats, the immunohistochemical reaction for HSP 70 was significantly higher compared to control groups (Student's t-test $\mathrm{P}<0.001$ ).

10 days after giving birth the intensity of reaction lowered; however, the change was better observable in the control than in the experimental group (Fig. 4).

The reaction for $\mathrm{p}-53$ protein on the $20^{\text {th }}$ day of control pregnancy was significantly statistically higher (average area of positive immunohistochemical reaction $8061.50+/-233.37$ $\mu \mathrm{m}^{2}$ ), compared with the $10^{\text {th }}$ day of pregnancy (average area of positive immunohistochemical reaction 3063.35+/$\left.422.73 \mu \mathrm{m}^{2}\right)(\mathrm{p}<0.001)$, and 10 days after giving birth (average area of positive immunohistochemical reaction $3027.76+/$ $\left.405.70 \mu \mathrm{m}^{2}\right)(\mathrm{p}<0.001)$. On the $10^{\text {th }}$ day of pregnancy, it was on the same level as 10 days after giving birth $(\mathrm{p}=0.56)$.

There were no statistical differences between groups 1 and 3 $(\mathrm{p}=0.56)$.

The reaction for $\mathrm{p}-53$ protein on the $20^{\text {th }}$ day of experimental pregnancy (average areas of positive immunohistochemical reaction $10697.67+/-1658.25 \mu^{2}$ ) was statistically significantly higher, compared with the $10^{\text {th }}$ day of pregnancy (average areas of positive immunohistochemical reaction 4104.69+/$\left.265.78 \mu \mathrm{m}^{2}\right)(\mathrm{p}<0,001)$, and 10 days after giving birth (average areas of positive immunohistochemical reaction $3060.64+/$ 308.75) $\mu \mathrm{m}^{2}(\mathrm{p}<0,001) .10$ days after delivery, it became significantly statistically lower in relation to the $10^{\text {th }}$ and $20^{\text {th }}$ day of pregnancy $(\mathrm{p}=0.002)$.

The reaction for $\mathrm{p}-53$ protein in experimental groups on the $10^{\text {th }}$ day of pregnancy was increased, compared with the same period during physiological pregnancy

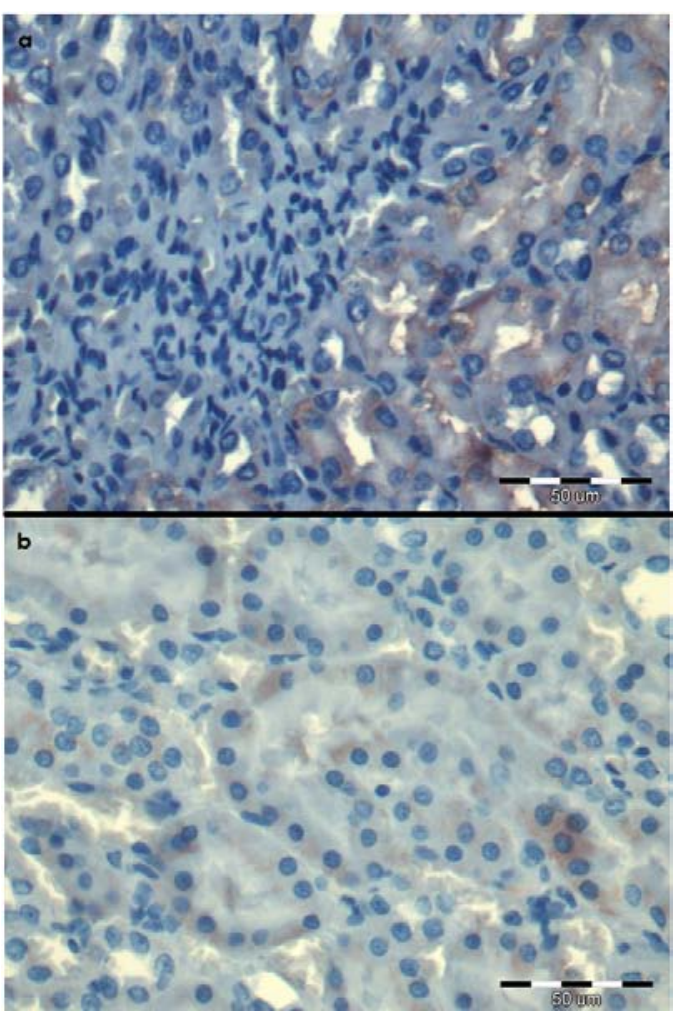

Figure 5. Kidney section of rat decapitated the $10^{\text {th }}$ day of pregnancy. Weak p-53Immunohistochemical reaction. a - Experimental group 1: pregnant rats treated with L-ARG b - Control group 2: pregnant rats treated with $\mathrm{Na} \mathrm{Cl}$. AEC+H staining

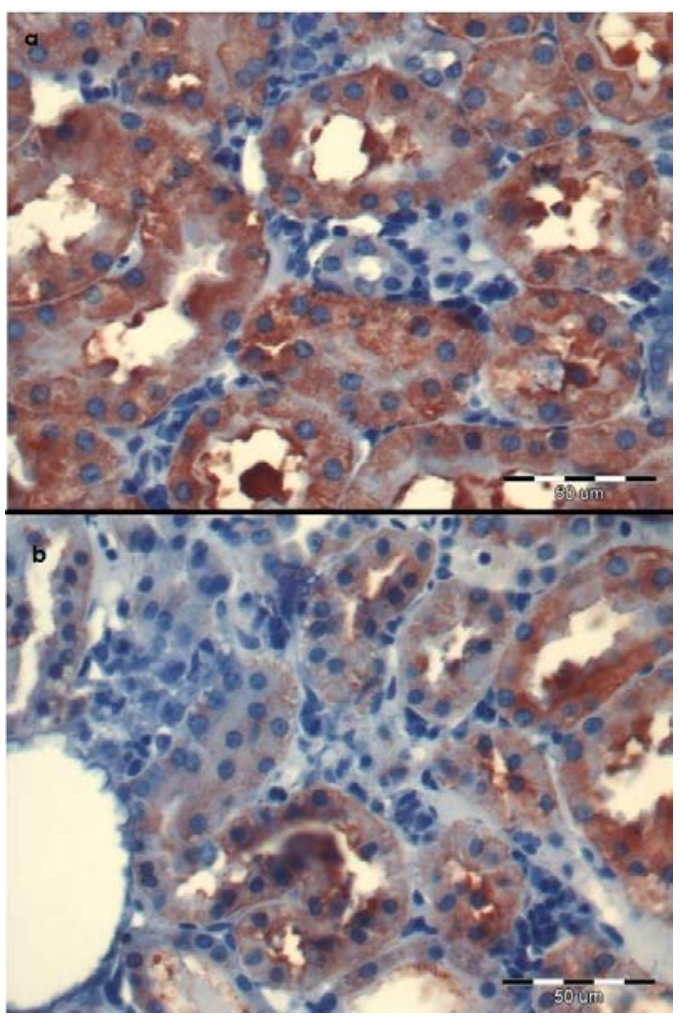

Figure 6. Kidney section of rat decapitated on the $20^{\text {th }}$ day of pregnancy. Intensive p-53 mmunohistochemical reaction. a - Experimental group 3: pregnant rats treated with L-ARG; b - Control group 4: pregnant rats treated with $\mathrm{Na} \mathrm{Cl}$. $\mathrm{AEC}+\mathrm{H}$ staining 


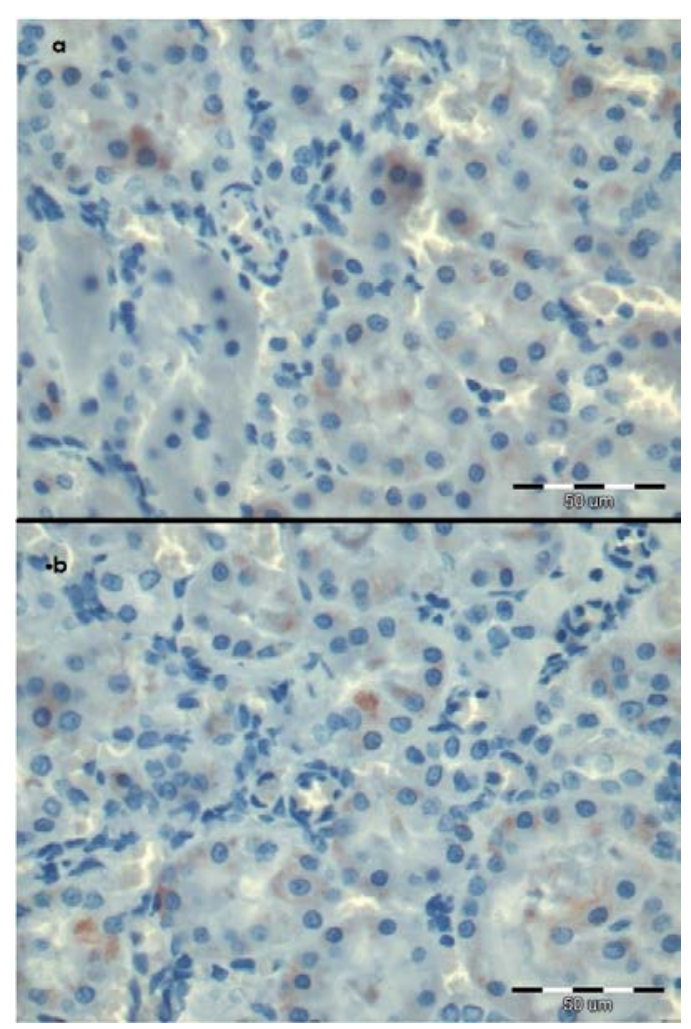

Figure 7. Kidney section of rat decapitated on the $10^{\text {th }}$ day after delivery. Weak p-53 immunohistochemical reaction. Experimental group 5: pregnant rats treated with L-ARG; b - Control group 6: pregnant rats treated with $\mathrm{Na} \mathrm{Cl}$. $\mathrm{AEC}+\mathrm{H}$ staining

$(\mathrm{p}<0.001)$. On the $20^{\text {th }}$ day it also increased significantly more compared with the corresponding control group $(\mathrm{p}<0.001) .10$ days after delivery, it significantly dropped in the experimental group to the level perceived as the lowest in comparison with all the other groups. There were no statistical differences between the control group on the $10^{\text {th }}$ day of pregnancy and the experimental group 10 days after giving birth ( $\mathrm{p}=0.99) .10$ days after delivery, the reaction for $\mathrm{p}-53$ was the same in the control and the experimental group $(\mathrm{p}=0.92)$ (Fig. 8).

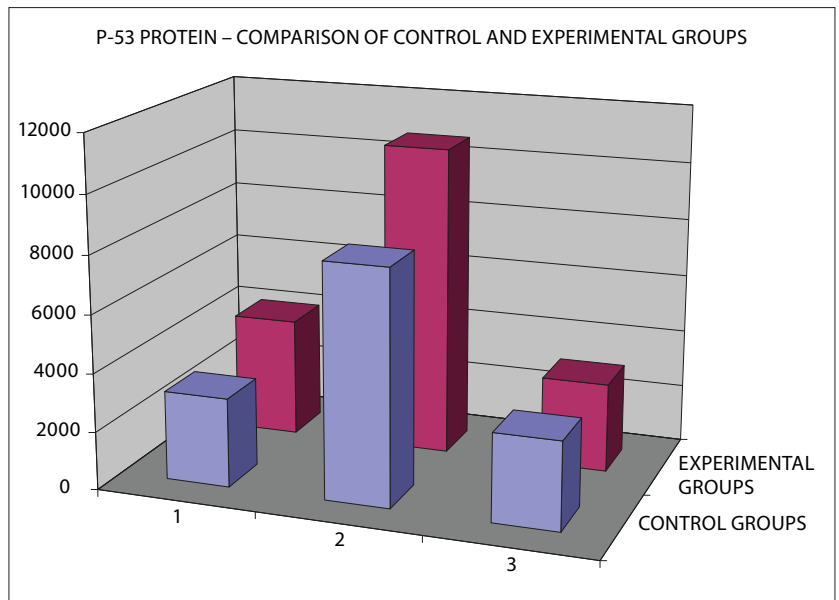

Figure 8. Comparison of the average area of positive immunohistochemical reaction expressed in $\mu \mathrm{m}^{2}$ for $\mathrm{p}-53$ in control and experimental groups $\left(1-10^{\text {th }}\right.$ day of pregnancy, $2-20^{\text {th }}$ day of pregnancy, $3-10^{\text {th }}$ day after delivery)

\section{DISCUSSION}

Kidneys are organs characterized as those showing the earliest reaction in the form of changes in cell metabolism and morphology during pregnancy. The changes mainly concern renal pelvises and ureters widening during pregnancy under the influence of progesterone. Their average capacity increases from 10 to $40 \mathrm{ml}$. The changes in the activity of kidneys in pregnant individuals consist in increasing the blood flow through kidneys by $50 \%$, as well as glomerular filtrate by $35 \%$. This leads to an intensification of the function of renal cells that resorb many substances: sugars, amino acids, water, mineral salts, folic acid, vitamins and iodine. The increased glomerular filtration is accompanied by an increased secondary resorption in renal tubules. Thanks to this increase in the resorption of the renal tubules, no significant dysfunctions related to the loss of substances important for the mother's organism are noted. What is particularly strongly expressed in renal tubules is sodium retention, stimulated by the RAA system (renin-angiotensinaldosterone system). Sodium retention is accompanied by a stoppage of water extraction in the amount of ca. 8 litres. In advanced pregnancy, the growing uterus presses against the ureters causing deceleration of urine flow. An increase in renal flow, on the other hand, causes a rise in the release of motherly and placenta hormones (ACTCH, vasopressin, cortisol, thyroxine, placental somatrotropin), as well as oncotic pressure related to the increased secondary sodium and water resorption, causing the growth of gromelural filtration by $50 \%$. Such a growth is accompanied by an impairment of resorption capacity of the urethrae with regard to the filtered glucose - leading to glycosuria, and physiological proteinuria in pregnancy amounting to 200$300 \mathrm{mg}$ per day.

The signal to initiate a pathological process in a cell is an increased expression of heat shock proteins: HSP 70 and $\mathrm{p}-53$, which regulate numerous vital processes of cells [12]. In 2000, Malyshev et al. noticed a co-relation between NO synthesis stimulation and HSP-70[13]. An increase of the heat shock protein, HSP-70, inhibits overproduction of endogenous nitric oxide [14] which could lead to an impairment of the apoptosis process, thus leading to numerous diseases.

An increased expression of a cellular stress biomarker for the HSP-70 protein was observed in the presented study as early as on the $10^{\text {th }}$ day of pregnancy. This level was maintained until the end of pregnancy and decreased 10 days after delivery.

Oxidation stress is a factor destabilising the functioning of cells and tissues [15].

The regular pregnancy is connected with an intensification of oxidative stress (physiological adaptation changes in the mother's circulatory system). An excess production of free radicals or their insufficient elimination may constitute the reason for pathologies characterized by clinical symptoms.

The expression of a genome guardian, $\mathrm{p}-53$ protein in the current study was analogous to the observed apoptosis in kidney cells: it increased on the $20^{\text {th }}$ day of pregnancy, whereas on the $10^{\text {th }}$ day it was the same as 10 days after delivery. An increased concentration of $\mathrm{p}-53$ protein has the capacity to induce apoptosis (pro-apoptotic effect, a high concentration of nitric oxide leading to deamination of nitric alkali of the DNA) [16]. 
The presented study also aimed to examine the impact of exogenous NO on the epithelial cells of the renal tubules of pregnant female rats. For this purpose, the females were administered L-arginine as a substrate of nitric oxide. L-arginine is applied in gynaecology to widen vessels and lower hypertension in gestosis in the clinical dose of $40 \mathrm{mg} /$ $\mathrm{kg}$ of body mass every other day.

Rytlewski, et al. observed a favourable effect of L-arginine administered orally to pregnant women with hypertension in order to prevent gestosis, as nitric oxide deficiency plays an important role in hypertension during pregnancy [17]. Pokrovskii et al. in their investigation noticed that L-arginine corrects endothelial dysfunction in experimentally-induced pre-eclampsia [18]. Similar observations were made by Manitus [19]. A researcher speculated in Circulation Research that the reason for pre-eclampsia is a decreased level of nitric oxide in blood, caused by an increased level of S-nitrosothiol (its level is twice as high in patients in the state of preeclampsia than in healthy women). A decrease in the level of S-nitrosothiol prevents NO from being released and relaxing the blood vessels, thus leading to a growth in arterial blood pressure. NO synthase inhibition in animals induces hypertension, whereas the development of pregnancyinduced hypertension is caused by a dysfunction in the L-arginine-NO model with the deactivation of adenytyl cylases in the endothelium, and lowers the concentration of cyclic 3" 5" guanethidine monophosphate (cGMP). According to research, pregnancy-induced hypertension constitutes a complication in $10 \%$ of all pregnancies (NIC) and is the third cause of mothers' deaths [20]. The aetiology, however, remains unknown. Perhaps the reason may be an observable increase of $\mathrm{Ca}+2$ activity in women's uterine arteries - a dependent constitutive NO synthase, an increase of cGMP level dependent on NO [21].

An objective of the conducted study was to examine whether L-arginine itself causes changes in kidneys, as well as to explore its meaning for clinical treatment. In 2004, Evans et al, and in 2005, Rytlewski et al., noticed that the dose of $3 g$ of L-arginine per day is sufficient to decrease pregnancy-induced hypertension. [22, 23]. Facchinetti et al. administered $30 \mathrm{~g}$ of $\mathrm{L}$-arginine in a medication drip [24]. The dose administered in the presented study was approximate to that used for pregnant women in gestosis treatment, calculated per $\mathrm{kg}$ of body weight. This is a dose sweeping off free radicals - safe both for the mother and the foetus [25]. Neri et al. in their experiment indicated that acute, intravenous administration of a high-dose of L-arginine does not induce significant changes in the foetal heart rate (FHR), whereas it lowers maternal blood pressure [26]. There are no investigations on this topic on mothers' kidneys in scientific literature.

$\mathrm{L}$-arginine increased the expression of $\mathrm{p}-53$ protein on the $10^{\text {th }}$ day of pregnancy, which increased at the end of pregnancy; however, 10 days after delivery, its level dropped below that observable during physiological pregnancy. Perhaps the administration of exogenous nitric oxide (which is the reason for apoptosis disturbance leading to numerous conditions) inhibited the synthesis of endogenous $\mathrm{NO}$ by inducing an overproduction of HSP 70 [27].

Hormonal changes in physiological pregnancy cause an increase in the expression of p-53 (cell stress marker) in the epithelial cells of renal tubules, mainly at the end of pregnancy (20th day). 10 days after delivery, this expression decreases. The expression of HSP-70 protein increases already on the 10th day of pregnancy, and maintains a similar level throughout the pregnancy. It is reduced after the puerperium.

\section{CONCLUSIONS}

Both control (physiological) and experimental (after L-arginine) pregnancies are stressful factors for the cells of mothers' kidneys. The presented study shows that cellular stress increases after L-arginine much more than in physiological pregnancy. This can led to excessive cell death. The growing of kidneys is due to enlargement of cells' size, not to increase in number. The death of a kidney's cells can reduce its function. The decrease in cell stress biomarkers (HSP70, p-53) expression, observed in this study after puerperium, is a symptom of finishing the harmful factor (pregnancy and L-arginine). There is a possibilitythat doses of L-arginine different (bigger) than in this study could significantly destroy the kidneys' function. This needs future investigations.

\section{REFERENCES}

1. Fikus M. Przyzwoitki dla biofizyka. Wiedza i życie. 2000; 4: 22-25 (in Polish).

2. Haupt S, Beraer M, Goldberg Z, Haupt Y. Apoptosis-the p53 network. J Cell Sci. 2003; 116: 4077-4085.

3. Ramaglia V, Buck LT. Time-dependent expression of heat shock proteins 70 and 90 in tissues of the anoxic western painted turtle. J Exp Biol. 2004; 207: 3775-3784.

4. Grudniak AM, Kuć M, Wolska KI. Role of Escherichia coli DnaK and DnaJ chaperones in spontaneous and induced mutagenesis and their effect on UmuC stability. FEMS Microbiol Lett. 2005; 242: 361-366.

5. Smith O. Cancer. Nota bene: The killer instinct of a p53 target. Science. 2000; $290: 67$.

6. Yoo JL, Janz DM. Tissue-specyfic HSP 70 levels and reproductive physiological responses in fishes inhabiting a metal-contaminated creek. Arch Environ Contam Toxicol. 2003; 45: 110-120.

7. Evans TG, Yamamoto Y, Jeffery WR, Krone PH. Zebrafish Hsp 70 is required for embryonic lens formation. Cell Stress Chaperones. 2005; 10: 66-78.

8. Hsu YL, Kuo PL, Tzeng WS, Lin CC. Chalcone inhibits the proliferation of human breast cancer cell by blocking cell cycle progression and inducing apoptosis. Food Chem Toxicol. 2006; 44: 704-713.

9. Chmielewski M, Linke K, Zabel M, Szuber L. Apoptosis in the liver. Gastroent Pol. 2003; 10: 453-462.

10. Guicciardi ME, Gores GJ. AIP1: a new player in TNF signaling. J Clin Invest. 2003; 111: 1813-1815.

11. Djukic M, Jovanovic MD, Ninkovic M, Stevanovic I, Curcic M, Topic A, Vujanovic D, Djurdjevic D. Intrastriatal pre-treatment with L-NAME protects rats from diquat neurotoxcity. Ann Agric Environ Med. 2012; 19: 666-672.

12. Fikus M. Chaperones for biophysicist. Wiedza i życie. 2000; 4: 22-25.

13. Malyshev IYu, Bayda LA, Trifonov AI, Larionov NP, Kubrina LD, Mikoyan VD, Vanin AF, Manukhina EB. Cross-talk between nitric oxide and HSP70 in the antihypotensive effect of adaptation to heat. Physiol Res. 2000; 49: 99-105.

14. Harris MB, Blackstone MA, Ju H, Venema VJ, Venema RC. Heatinduced increases in endothelial NO synthase expression and activity and endothelial NO release. Am J Physiol Heart Circ Physiol. 2003; 285: H333-H340.

15. Mohanty S, Sahu PK. Evaluation of oxidative stress in pregnancy induced hypertension. J Clin Biochem. 2006; 21: 101-105.

16. Biesiak L, Pietrzak Z, Brocka U. Some factors of oxidative stress in pregnancy with preeclampsia and cholestasis Gin Pol. 2007; 78: 956960.

17. Rytlewski K, Zdebski T. Nitric oxide as a mechanism covering pregnancy. Gin Pol. 2001; 72: 758-743. 
18. Pokrovskiı̌ MV, Pokrovskaia TG, Gureev VV, Barsuk AA, Proskuriakova EV, Korokin MV, Gudyrev OS, Belous AS, Kochkarov VI, Danilenko LM, Levashova OV, Mal'tseva NV, Polianskaia OS. Correction of endothelial dysfunction by L-arginine under experimental preeclampsia conditions. Eksp Klin Farmakol. 2012; 75: 14-16.

19. Manitus J. From organogenesis to chronic renal failure and hypertension. Post Nauk Med. 2009; 10: 744-750.

20. Morris JM, Algert CS, Falster MO, Ford JB, Kinnear A, Nicholl MC, Roberts CL. Trends in planned early birth: a population-based study. Am J Obstet Gynecol. 2012; 207: 186-188.

21. Nelson SH, Steinsland OS, Wang Y, Yallampalli C, Dong YL, Sanchez JM. Increased nitric oxide synthase activity and expression in the human uterine artery during pregnancy. Circ Res. 2000; 87: 406-411.

22. Evans RW, Fernstrom JD, Thompson J, Morris SM Jr, Kuller LH. Biochemical responses of healthy subjects during dietary supplementation with L-arginine. J Nutr Biochem. 2004; 15: 534-539.
23. Rytlewski K, Olszanecki R, Korbut R, Zdebski Z. Effects of prolonged oral supplementation with 1 -arginine on blood pressure and nitric oxide synthesis in preeclampsia. Eur J Clin Invest. 2005; 35: 32-37.

24. Facchinetti F, Longo M, Piccinini F, Neri I, Volpe A. L-arginine infusion reduces blood pressure in preeclamptic women through nitric oxide release. J Soc Gynecol Investig. 1999; 6: 202-207.

25. Gupta V, Gupta A, Saggu S, Divekar HM, Grover SK, Kumar R. Antistress and Adaptogenic Activity of 1-Arginine Supplementation. Evid Based Complement Alternat Med. 2005; 2: 93-97.

26. Neri I, Blasi I, Facchinetti F. Effects of acute L-arginine infusion on nonstress test in hypertensive pregnant women. J Matern Fetal Neonatal Med. 2004; 16: 23-26.

27. Hashimoto S, Takahashi K, Amiel D, Coutts RD, Lotz M. Chondrocyte apoptosis and nitric oxide production during experimentally induced osteoarthritis. Arthritis Rheum. 1998; 41: 1266-1274. 